Sari Pediatri, Vol. 7, No. 4, Maret 2006: 232 - 236

\title{
Hernia Bochdalek
}

\author{
IGN Sanjaya Putra*, Abdul Hamid**, IN Semadi***
}

\begin{abstract}
Hernia diafragmatika adalah masuknya organ-organ abdomen melalui defek (lubang) pada diafragma ke dalam rongga toraks. Secara umum terdapat tiga tipe dasar hernia diafragmatika yaitu hernia Bochdalek (melalui defek posterolateral), hernia Morgagni (melalui defek anterio retrosternal) dan hiatus hernia. Diagnosis ditegakkan berdasarkan anamnesis, gejala klinik, pemeriksaan radiologik, dan laboratorium. Insiden pasti hernia diafragma sulit diperkirakan karena separuhnya meninggal dalam kandungan atau meninggal saat neonatus belum dibawa ke pusat rujukan atau sebelum diagnosis ditegakkan. Insiden hernia Bochdalek dilaporkan $1: 2000-4000$ kelahiran hidup dengan perbandingan jenis kelamin laki-laki : perempuan adalah 1,5:1. Hernia Bochdalek memberikan gejala kardiopulmonal yang berat, seperti sesak nafas segera setelah lahir dengan mortalitas yang tinggi, 40-50\% sebelum pemakaian dan $30 \%$, setelah pemakaian Extracorporeal Membrane Oxygenation (ECMO). Pembedahan dilaksanakan setelah kondisi bayi stabil.
\end{abstract}

Kata Kunci: hernia Bochdaleck, sesak napas, ECMO

$\mathcal{H}$ rnia diafragmatika adalah masuknya organorgan abdomen melalui defek pada diafragma ke dalam rongga dada. Penyebab hernia diafragmatika yang sering dijumpai adalah kelainan diafragma yang bersifat bawaan walaupun masih ditemui kelainan yang didapat ${ }^{1}$

Secara umum terdapat tiga tipe dasar hernia diafragmatika kongenital yaitu hernia Bochdalek (posterolateral), hernia Morgagni (retrosternal atau anterior), dan hiatus hernia yaitu masuknya esofagus abdominal dan cardia gaster ke dalam rongga dada

\footnotetext{
Alamat korespondensi:

Dr. IGN Sanjaya Putra*

PPDS IKA FKUNUD-RS Sanglah, Bagian Ilmu Kesehatan Anak. Jl P Nias Denpasar Bali

Tel 0361-244038, Fax. 0361- 257387.
}

Prof. Dr. Abdul Hamid Sp.A(K)**, Subbagian Neonatologi Bagian Ilmu Kesehatan Anak, FKUNUD-RS Sanglah, Denpasar Bali dan Dr. I N Semadi Sp.BTKV***, Subbagian Bedah Thorax, FKUNUD-RS Sanglah, Denpasar Bali. melalui pelebaran hiatus esofagus. Hernia Bochdalek terjadi karena kegagalan penutupan membran pleuroperitoneal kiri, sedangkan hernia Morgagni timbul karena kegagalan bersatunya otot rusuk dan sternal. ${ }^{1,2}$ Hernia diafragmatika kongentinal yang paling sering ditemui adalah hernia Bochdalek dengan insiden 1 dari 2000-4000 kelahiran hidup.

Diagnosis hernia Bochdalek dapat ditegakkan saat antenatal dan perinatal berdasarkan anamnesis adanya polihidramnion, diagnosis fisik adanya tanda distres nafas dan terdengarnya bising usus di rongga dada serta bergesernya suara jantung ke kanan, secara laboratoris adanya gangguan pertukaran udara pada dengan pemeriksaan radiologis dada (perinatal) dan USG (antenatal), serta pemeriksaan penunjang lainnya. ${ }^{3}$ Tata laksana yang dilakukan meliputi terapi medikamenmtosa, suportif, dan koreksi pembedahan untuk mengembalikan organ abdomen yang terdapat di dalam rongga dada ke abdomen. ${ }^{2,4,5}$ Saat ini diagnosis dan terapi hernia Bochdalek dapat dikerjakan saat antenatal. Diagnosis antenatal yang dapat dikerjakan adalah USG, 
sedangkan terapi antenatal yang dapat dilakukan adalah dengan obat-obatan dan pembedahan (fetal surgery). Secara umum prognosis penderita tergantung pada komplikasi hernia dan fasilitas yang tersedia.

\section{Definisi}

Hernia Bochdalek dikenal juga sebagai hernia diafragmatika posterolateral, yaitu herniasi intestinal dan kadang-kadang lien dan hepar melalui defek di daerah posterolateral dari diafragma. ${ }^{1,2}$

\section{Patofisiologi}

Pada usia kehamilan 2 bulan tidak ada penekanan terhadap diagfragma yang sedang berkembang baik dari rongga dada maupun dari rongga abdomen. Di dalam rongga dada, paru belum berkembang, sedangkan di dalam rongga abdomen usus mengambil tempat di luar abdomen yaitu di umbilikus. Tekanan mekanik pertama yang diterima oleh diafragma adalah saat usus kembali dari umbilikus ke intra abdomen pada minggu ke-10. Saat itu bagian-bagian diafragma telah menempati tempat yang normal untuk menerima penekanan sebagai konsekuensi dari perkembangan organ-organ. Hernia dapat timbul dari gagalnya pertumbuhan diafragma yang normal atau timbul dari daerah yang memang rawan terhadap penekanan yaitu foramen Bochdalek, foramen Morgagni, dan hiatus esofagus. ${ }^{6}$

Gangguan pembentukan diafragma ini dapat berupa kegagalan pembentukan sebagian diafragma, gangguan fusi antar unsur-unsur pleuroperitonei atau gangguan pembentukan otot, yang dapat menyebabkan diafragma menjadi tipis dan mengakibatkan terjadi eventrasi, ${ }^{5}$ sedangkan pelebaran tentang hiatus esofagus dan lemahnya ligamentum phrenoesophageal tidak diketahui secara jelas. ${ }^{3}$

\section{Insiden}

Insiden hernia Bochdalek berkisar 1 dari $2000-4000$ kelahiran hidup dengan perbandingan jenis kelamin laki-laki : perempuan 1,5:1, merupakan $8 \%$ dari seluruh anomali kongenital mayor, serta terbanyak timbul di daerah sebelah kiri. Risiko timbulnya hernia Bochdalek pada kelahiran berikutnya sekitar $2 \% .^{2}$

\section{Etiologi}

Belum diketahui secara pasti, dan tidak ada satupun mutasi gen yang bertanggung jawab terhadap terjadinya kelainan ini. ${ }^{2}$ Hernia diafragmatika kongenital familial sangat jarang dijumpai dan diduga melibatkan banyak faktor atau suatu pola autosomal resesif. ${ }^{2}$ Skarsgard dan Harrison $^{7}$ mengemukakan suatu studi populasi yang menunjukkan 30\% dari janin dengan hernia diafragmatika meninggal sebelum lahir dan terkait dengan kelainan kromosom atau kongenital lain yang letal.

\section{Diagnosis Hernia Bochdalek}

Diagnosis hernia Bochdalek dapat ditegakkan saat antenatal dan perinatal berdasarkan

Anamnesis: terdapat polihidramnion $80 \%$ kasus hernia Bochdalek disertai dengan polihidramnion. ${ }^{7}$

Manifestasi klinis: distres pernapasan (Apgar score rendah) merupakan manifestasi klinis hernia diafragmatika yang dapat terjadi segera setelah lahir atau timbul 24- 48 jam setelah periode stabil. Manifestasi awal meliputi takipneu, grunting, retraksi dinding dada, pucat, sianosis dan tanda klinis shunting dan persistent fetal circulation. ${ }^{5}$

Pada pemeriksaan fisik didapat abdomen yang scaphoid, barrel chest, distress nafas/ sianosis dan pulsasi apeks jantung ke arah kontralateral. Keempat kelainan ini (tetrad) merupakan salah satu kriteria penting untuk penentuan diagnosis. ${ }^{5}$ Peristaltik pada sisi toraks yang terkena, tidak selalu terdengar pada auskultasi. ${ }^{3}$ Keadaan klinis yang dominan menurut Johnson dan Steinberg ${ }^{3}$ adalah terganggunya fungsi pernapasan akibat desakan abdomen terhadap paru, hipoplasia paru, dan hipertensi pulmonal yang akhirnya dapat menimbulkan gagal napas akut.

\section{Laboratorium}

Analisis gas darah, untuk menentukan adanya asidosis respiratorik akibat distress nafas, analisis gas darah dapat sebagai indikator sederhana untuk menilai derajat hipoplasia paru dan dapat diduga adanya hipoplasia paru yang berat bila $\mathrm{PCO}_{2}$ diatas 50 torr. ${ }^{7}$ Pemeriksaan kromosom, untuk membantu menemukan adanya kelainan kongenital lain sehingga dapat diperkirakan penyulit yang mungkin terjadi. Kadar elektrolit serum, 
sebaiknya diperiksa dan dimonitor untuk mempertahankan homeostasis. ${ }^{2,3}$

\section{Pemeriksaan radiologis}

Pada foto dada ditemukan gambaran udara intestinal dalam rongga dada. Pemasangan pipa orogastric dapat membantu menentukan posisi lambung (intra abdominal atau intra thorakal). Pada hernia Bochdalek kiri dapat ditemukan adanya gambaran udara atau cairan usus pada hemitorak kiri dan pergeseran bayangan jantung ke kanan. Pemeriksaan radiologis dada juga dapat menentukan ada tidaknya pneumothorax. ${ }^{2,3,7}$

Ultrasonografi (USG), pemeriksaan USG jantung untuk mengetahui adanya kelainan jantung bawaan. USG ginjal diperlukan untuk menentukan ada tidaknya kelainan saluran urogenital. ${ }^{2}$ USG kepala diperlukan untuk evaluasi adanya perdarahan intraventrikular, infark, atau kelainan intrakranikal yang lain. Sedangkan USG antenatal (in utero) dapat mendeteksi adanya polihidramnion (80\% kasus hernia Bochdalek disertai dengan polihidramnion), tidak terdapat gambaran udara dalam lambung di rongga abdomen, terdapat gambaran udara lambung dalam rongga dada, pergeseran mediastinum dan proyeksi jantung, dan walaupun jarang mungkin terdapat gambaran hydrops fetalis. 3,7

Pemasangan pulse oximetry, sangat membantu dalam diagnosis dan tata laksana hipertensi pulmonal persisten yang timbul akibat adanya hipoplasia pulmonal. Pulse oximetry dipasang pada preductal (tangan kanan) dan postductal (kaki sisi berlawanan) untuk menentukan adanya shunt kanan ke kiri pada ductus arteriosus. ${ }^{2,3}$

Ekokardiografi, Suda ${ }^{13}$ meneliti pemakaian ekokardiografi pada bayi baru lahir dengan hernia Bochdalek dan mengemukakan bahwa terdapat korelasi terbalik antara hubungan arteria pulmonalis kiri dengan derajat hipoplasia paru.

\section{Karyotyping}

Karyotyping tidak selalu membawa hasil yang menunjukkan kelainan kromosom. Steinhorn dan Hollands mengemukakan bahwa $4 \%$ dari bayi yang hernia Bochdalek memiliki kelainan kromosom yang bervariasi seperti trisomi 13 , trisomi 18 , dan tetrasomi $12 \mathrm{p}$ mosaik. Hernia Bochdalek juga dapat berhubungan dengan kelainan non kromosomal seperti "de Lange syndrome."

\section{Diagnosis Banding}

Sebagai diagnosis banding adalah pneumatokel akibat stafilokokus, malformasi kista adenomatoid paru, eventrasi dan paralisis diafragma, yang juga dapat menimbulkan kesukaran bernapas. Untuk membedakan satu dengan yang lain harus dilakukan pemeriksaan foto dada dan fluoroskopi. ${ }^{9}$

Pada pneumomatokel dan malformasi kista adenomatoid, gambaran foto dada tidak menunjukkan adanya rongga dada berisi usus atau organ-organ viscera lain (biasanya $80 \%$ pada sisi kiri) yang bayangannya bersambung dengan bayangan usus dan organ visera dalam rongga perut. Pada foto abdomen tidak ditemui adanya marked excess of gas di bawah diafragma. Untuk memastikannya perlu dilakukan pemeriksaan foto dada dengan pemasangan NGT sebagai petunjuk adanya lambung di dalam rongga dada. ${ }^{5}$

Eventrasi diafragma merupakan duplikasi hernia diafragmatika bawaan sehingga bila hanya berdasarkan pemeriksaan fisik dan foto dada saja keduanya sering sukar dibedakan. Pemeriksaan foto dada hanya menunjukkan peninggian diafragma sedangkan pada pemeriksaan fluoroskopi mula-mula terlihat gerakan diafragma berkurang dan akhirnya menunjukkan gerakan paradoksal. ${ }^{10}$ Paralisis diafragma oleh karena trauma maupun bawaan, baik yang bersifat sementara atau menetap, pada pemeriksaan foto toraks terlihat letak diafragma yang makin lama makin meninggi, sedangkan bila dilakukan pemeriksaan fluoroskopi terlihat pergerakan diafragma berkurang yang pada akhirnya menunjukkan gambaran paradoksal. ${ }^{9}$

\section{Tata laksana Hernia Bochdalek}

Konseling prenatal dilakukan segera setelah diagnosis dibuat berdasarkan USG. Setelah melalui berbagai pemeriksaan tersebut, tim medis harus menjelaskan segala kemungkinan pilihan tata laksana kepada orang tua seperti terminasi kehamilan, meneruskan kehamilan dan melahirkan bayi tersebut di pusat pelayanan medis yang memadai termasuk prognosis dari kasus ini. ${ }^{10}$ 
Tata laksana hernia Bochdalek yang optimal harus memperhatikan berbagai hal yang terkait dengan kelainan bawaan ini.

\section{Proses persalinan dan unit perawatan intensif neonatus}

Bayi harus dilahirkan di pusat kesehatan yang memiliki sarana bedah anak dan perinatologi yang memadai. ${ }^{7}$ Secara umum sarana yang diperlukan adalah intubasi endotrakeal dan pemakaian ventilator mekanik yang disesuaikan dengan derajat keparahan herniasi organ abdomen, (hindari pemakaian ventilasi dengan manual bag karena lambung dan organ intestinal akan distensi oleh udara yang berakibat semakin tertekannya paru dan organ-organ intratorakal), pemasangan pipa nasogastrik untuk dekompresi, menghindari pemakaian tekanan inspirasi yang tinggi. ${ }^{2}$

\section{Stabilisasi preoperatif}

Pada hernia diafragmatika terdapat paru yang hipoplastik, tidak atelektasis vaskularisasi arteriolar yang abnormal dan hipertensi pulmonal sehingga dipertimbangkan pembedahan ditunda atau dipersiapkan dahulu. ${ }^{11}$ Umur rata-rata untuk melakukan pembedahan adalah sekitar 72 jam. $^{7}$

\section{Ventilasi mekanik konvensional}

Pemberian ventilasi mekanik harus mempertimbangkan faktor-faktor yang diketahui meningkatkan resistensi vaskuler pulmonal (hipoksia, asidosis, hipotensi dan hiperkarbia). Ventilasi dengan inspirasi bertekanan rendah dipilih karena menurunkan kemungkinan terjadinya pneumothorax kontralateral yang dapat meningkatkan ketidakstabilan sistem kardiorespirasi dan dekompensasi. ${ }^{11}$ Jika dengan ventilasi mekanik konvensional ini gagal maka dipakai strategi ventilasi yang lain yaitu high-frequency oscillatory ventilation (HFOV), gentle ventilation dan intratracheal pulmonary ventilation (ITPV). Selain strategi ventilasi juga dibutuhkan terapi pendukung untuk menunjang keberhasilan pembedahan dan memperbaiki prognosis.

\section{Extracorporeal Membrane Oxygenation (ECMO)} Alat ECMO adalah perlengkapan paru buatan yang digunakan untuk mengembangkan sisa jaringan paru agar oksigenasi tetap adekuat selama pembedahan untuk mencegah gagal napas dan hipoksia berat. ECMO meningkatkan keberhasilan hidup bayi dengan hernia diafragmatika sebesar $42 \%$ pada era awal, menjadi sebesar $79 \%$ pada era sekarang ini. Waktu yang tepat untuk memberikan ECMO masih kotroversial. ${ }^{11}$

\section{Pemberian surfaktan}

Gagal nafas pada bayi dengan hernia diafragmatika dapat berhubungan dengan perkembangan paru yang abnormal dan defisiensi surfaktan. Studi postmortem menunjukkan adanya penurunan ekskresi surfaktan apoprotein A (SP-A) yang lebih berat pada sisi dengan hernia diafragmatika dibandingkan dengan sisi yang lain. Hal ini menunjukan adanya penundaan pematangan fungsional atau perkembangan dan sintesis SP-A. Analisis cairan amnion mendukung kenyataan tersebut. Surfaktan sebaiknya diberikan segera saat bayi menarik nafasnya untuk pertama kali.

\section{Terapi antenatal}

Pemberian glukokortikoid antenatal untuk memperbaiki maturitas paru dan meningkatkan oksigenasi serta kemampuan paru. ${ }^{11}$

\section{Terapi pembedahan perinatal}

Davis dkk. ${ }^{10}$ mengungkapkan bahwa pembedahan yang dipersiapkan lebih dahulu diikuti dengan terapi ECMO memberikan hasil yang lebih baik. Waktu yang tepat untuk melakukan pembedahan belum diketahui dengan pasti, beberapa ahli menganjurkan pembedahan dapat dilakukan 24 jam setelah bayi stabil, tetapi penundaan sampai 7-10 hari dapat juga ditoleransi. Banyak ahli bedah lebih menyukai operasi dikerjakan saat ekokardiografi menunjukkan tekanan arteri pulmonalis stabil dalam 24-48 jam. $^{2}$ Drainase dengan chest tube diperlukan bila terdapat tension pneumothorax. ${ }^{2}$ Prinsip pembedahan adalah mengembalikan organ abdomen pada tempatnya.

\section{Transplantasi paru}

Transplantasi paru adalah salah satu teknik pembedahan dalam upaya mengurangi efek buruk distres pernapasan pada bayi dengan hernia Bochdalek akibat hipoplasia paru berat yang gagal dengan terapi suportif pernapasan, namun pengobtan ini masih memerlukan penelitian lebih lanjut. ${ }^{13}$ 


\section{Perawatan pasca bedah}

Perawatan pasca bedah meliputi perawatan jangka pendek (segera setelah pembedahan) dan perawatan jangka panjang. ${ }^{2}$

Perawatan jangka pendek: Perawatan pasca bedah jangka pendek meliputi deteksi dan tata laksana komplikasi yang dapat terjadi setelah pembedahan. Komplikasi yang mungkin timbul dapat berupa perdarahan, distres pernapasan, hipotermia, produksi urin yang menurun, infeksi dan obstruksi usus. ${ }^{14}$ Pengawasan yang dilakukan saat pasien masih dirawat di rumah sakit meliputi monitoring pernapasan, evaluasi neurologis, dan masalah pemberian makanan.

Perawatan jangka panjang: Perawatan pasca bedah jangka panjang meliputi pemantauan tumbuh kembang pasien. Pertumbuhan kasus dipantau karena risiko terjadi gagal tumbuh besar akibat adanya penurunan asupan kalori sebagai akibat penyakit paru kronis, gastroesophageal refluk dan feeding yang buruk terutama pada pasien dengan defek neurologis yang berat. ${ }^{14}$

\section{Prognosis}

Losty $^{15}$ mengungkapkan mortalitas hernia diafragmatika sebesar $40-50 \%$. Steinhorn dan Holland ${ }^{2}$ mengungkapkan prognosis bervariasi tergantung pada institusi tempat pasien dirawat; apabila fasilitas memadai termasuk perawatan dengan ECMO tersedia, maka angka keberhasilan hidup berkisar antara 40-69\%. Hal- hal yang mungkin timbul dan dapat mempersulit kondisi pasien yang bertahan hidup dengan morbiditas jangka panjang meliputi kelainan fungsi paru dan penyakit paru kronis, gastroesophageal reflux, rehernia, volvulus, scoliosis, hearing loss dan gangguan perkembangan. ${ }^{10}$

\section{Daftar Pustaka}

1. Shanding B. Diaphragmatic hernia. Dalam: Behrman RE, Kliegman RM, Nelson WE, Vaughan VC, penyunting. Nelson Textbook of Pediatrics. Edisi keempat belas. Philadelphia: W.B. Saunders company, 2000. h. 1032-3.
2. Steinhorn RH, Hollands CM. Congenital diaphragmatic hernia. Diperoleh dari:http://www.emedicine.com/ ped/topic 2603.htm.

3. Johsons JM, Steinberg SR. Diaphragmatic hernia, congenital. Diperoleh dari: http://www.emedicine. com/med/ topic2979.htm.

4. Graeber GM, Miller JI, Davtyan J. Congenital hernias. Dalam: Pearson FG, Deslauriers J, Hiebert CA, Ginsberg R J, Mc Kneally MF, Urschel HC, penyunting. Thoracic surgery. Edisi pertama. New York: Churchill Livingstone, 1995. h. 1313-9.

5. Arensman RM, Bambini DA. Congenital diafragmatic hernia and eventration. Dalam: Ashcraff K W, penyunting. Pediatric Surgery. Edisi ketiga. Philadelphia: W.B. Saunders company, 2000. h. 300-13.

6. Nobuhara KK, Wilson JM. Pathophysiology of congenital diaphragmatic hernia. Seminar Pediatr Surg 1996; 5:234-42.

7. Skarsgard ED and Harrison MR. Congenital diaphragmatic hernia. A historical review. Clin Perinatol 1996; 23: 625-53.

8. VanderWall KJ, Kohl T, Adzick NS. Fetal diaphragmatic hernia: echocardiography and clinical outcome. Ped Surg J. 1997; 32:223-5.

9. Salzberg AM, Krummel TM. Congenital malformations of the lower respiratory tract. Dalam: Chemick V, Kendig E, penyunting. Disorders of the respiratory tract in children. Philadelphia: W.B. Saunders company, 1996. h. 227-36.

10. Davis CF, Sabharwal AJ. Annotation: Management of congenital diaphragmatic hernia. Arch Dis Chil Fetal Neonatal 1998; 79:F1-F3.

11. Meurs KV, Short BL. Congenital diaphragmatic hernia. Neonatologist's Perspective. Neo Reviews 1999; e79-e87.

12. Carlidge PHT, Mann NP, Kapila L. Preoperative stabilization in congenital diaphragmatic hernia. Arch Dis Child. 1986; 61:1225-8.

13. Suda K, Bigras JL, Bohn D, Homberger LK, McCrindle BW. Echocardiographic predictors of outcome in newborn with congenital diaphragmatic hernia. Pediatr 2000; 105:1106-9.

14. Halamek LP and El-Sayed YY. Congenital Diaphragmatic Hernia: Perinatologist's Perspective. Neo Reviews. 1999: e67-e70.

15. Losty PD. Pediatric Surgery. Br Med J 1999; 318: 1666-72. 